\title{
Wind Energy Assessment of the Zawiya Region, in Northwest Libya
}

\author{
Sarhan H. Alwan Hasan ${ }^{1}$, Abdulmunim Guwaeder ${ }^{2}$, Wenzhong Gao ${ }^{1}$ \\ ${ }^{1}$ Electrical and Computer Engineering, University of Denver, Colorado, USA \\ ${ }^{2}$ Electrical and Computer Engineering, Oklahoma State University, Oklahoma, USA \\ Email: *Sarhanhasan66@yahoo.com, guwaede@okstate.edu
}

How to cite this paper: Hasan, S.H.A., Guwaeder, A. and Gao, W.Z. (2017) Wind Energy Assessment of the Zawiya Region, in Northwest Libya. Energy and Power Engineering, 9, 325-331.

https://doi.org/10.4236/epe.2017.96022

Received: April 15, 2017

Accepted: June 20, 2017

Published: June 26, 2017

Copyright $\odot 2017$ by authors and Scientific Research Publishing Inc. This work is licensed under the Creative Commons Attribution International License (CC BY 4.0). http://creativecommons.org/licenses/by/4.0/

\begin{abstract}
The objective of this paper is to evaluate the annual, monthly and the seasonal performance of the wind resource at the Zawiya region in northwest of Libya. In this study, the wind data are obtained from the coastal site located in the northwest of Libya at height of 50 meters above the ground level. The results show that the annual average speed is $6.14 \mathrm{~m} / \mathrm{s}$, and the annual Weibull parameters are shape factor $K=3.2$, scale factor $C=6.9 \mathrm{~m} / \mathrm{s}$, and the annual energy production of $750 \mathrm{kw}$ wind turbine is $2.70 \mathrm{Gwh} /$ year.
\end{abstract}

\section{Keywords}

Zawiya Region, Libya, Weibull, Latitude

\section{Introduction}

The generated energy from renewable sources like wind reduces toxic gases released from traditional power plants, and saves oil consumption. Outfitting the wind is one of the cleanest, most reasonable approaches to create power. Wind vitality is the quickest developing wellspring of power on the planet. The wind is generated due to the pressure gradient comes from uneven heating of the earth's surface by the sun. As the very driving force causing this movement is derived from the sun, wind energy is basically being indirect form of solar energy; this means that the wind is driven by the temperature difference [1]. In this study, we analyze wind resource of the Zawiya region in Libya. The power demand in Libya increases each year. Based on a study of economic and Statistics Research Office at Ministry of Electricity of Libya, the energy demand will reach to 87.935 Gwh by the end of 2017 [2], where this cannot be covered by generation stations in the country. Renewable energy resources of both solar and wind are available along the $2000 \mathrm{~km}$ coast in Libya, south of the Mediterranean Sea. 


\section{Site and Weather Data}

In this paper, data obtained from the metrological coastal station have been analyzed [3]. The geographic coordinates of the site are summarized in Table 1. The measurements are made at 50 meters above the ground level. Figure 1 shows the location of the studied coastal station.

\section{Methodology}

\subsection{Weibull Distribution}

Weibull probability density function is commonly used and widely adopted in wind power study [4]. The Weibull distribution function is defined as:

$$
f(v)=\left(\frac{k}{C}\right)\left(\frac{V}{C}\right)^{K-1} \exp \left[-\left[\frac{V}{C}\right]^{K}\right]
$$

where $f(v)$ is the probability density function, and Parameters $\mathrm{k}, \mathrm{c}$ and $v$ are the shape factor (dimensionless), the scale factor $(\mathrm{m} / \mathrm{s})$, and wind velocity respectively. Usually, the shape factor describes the symmetry of the distribution, while the scale factor is very close to the average speed of the wind [2] [5]. The cumulative distribution function given in Equation (2) is the integral of the probability density function, and it can be used for estimating the time for which wind speed is within a certain speed period [6] [7].

$$
f(v)=1-\exp \left(-\left(\frac{v}{c}\right)^{k}\right)
$$

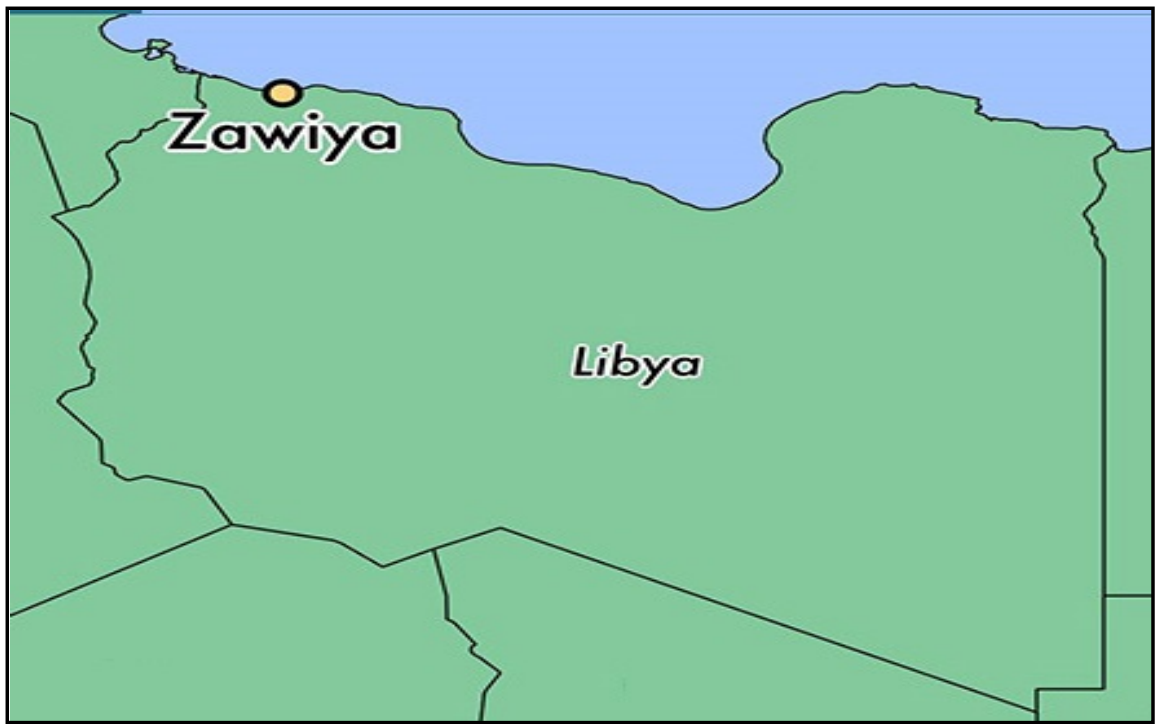

Figure 1. The Zawiya region on Libyan map.

Table 1. Geographical coordinates of the data collection station used in this study.

\begin{tabular}{ccccc}
\hline Location & Longitude & Latitude & Altitude $(\mathrm{m})$ & Measurement years \\
\hline Zawiya & $32.45 \mathrm{~N}$ & $12.43 \mathrm{E}$ & 17 & $\begin{array}{l}01 / 01 / 2013 \\
01 / 01 / 2016\end{array}$ \\
\hline
\end{tabular}




\subsection{Air Density and Wind Energy}

The air density affects the power generated by a wind turbine which can be expressed by the following equation [8]:

$$
P(v)=\frac{1}{2} \rho v^{3}
$$

where $\rho$ is density of the air $\left(\mathrm{Kg} / \mathrm{m}^{3}\right)$, and $s$ is swept area in $\mathrm{m}^{2}$.

The wind kinetic energy is converted to electrical energy by the wind turbine, and the effective power generated is expressed in the following relation [9] [10]:

$$
P_{e}(v)=C_{e^{*}} P(v)
$$

where $\mathrm{C}_{\mathrm{e}}$ is wind turbine efficiency, and the wind turbine technical specifications parameters for this site are listed in Table 2.

\section{Results and Discussion}

The wind analyses for the Zawiya region show that the annual shape factor $\mathrm{K}=$ 3.2 , and scale factor is $6.9(\mathrm{~m} / \mathrm{s})$, as illustrated in Table 3. The region is windy and promising with renewable energy. It can be observed from Figure 2 that the monthly mean speed at 50 meters high varies between $5.12 \mathrm{~m} / \mathrm{s}$ in July and a maximum value of $7.92 \mathrm{~m} / \mathrm{s}$ in February. Moreover, at $50 \mathrm{~m}$ high, the monthly mean power density varies between $155.81 \mathrm{w} / \mathrm{m}^{2}$ in July and $503.21 \mathrm{w} / \mathrm{m}^{2}$ in February as shown Table 4, while the mean monthly energy variation represents in Figure 3. For the cumulative speed distribution, Figure 4 illustrates that about $55 \%$ of speed frequencies is greater than $6 \mathrm{~m} / \mathrm{s}$. Figure 5 represents a monthly shape factor and scale factor of Weibull wind distribution. The result yields that the greatest shape factor $\mathrm{k}$ in July with 4.49 , and the worst value in April with 2.42. The result also yields good scale factor $\mathrm{C}$ with a greatest value in February equal to 7.92 .

Table 2. Wind turbine specifications.

\begin{tabular}{cc} 
Model & FL750 \\
Rated Power Kw & 750 \\
Rotor Diameter $(\mathrm{m})$ & 50 \\
Hub height $(\mathrm{m})$ & 50 \\
Cut-in Speed $(\mathrm{m} / \mathrm{s})$ & 3 \\
Rated wind Speed $(\mathrm{m} / \mathrm{s})$ & 14 \\
Cut-Out Speed $(\mathrm{m} / \mathrm{s})$ & 20 \\
Swept area of Rotor $\left(\mathrm{m}^{2}\right)$ & 1960 \\
Efficiency $\%$ & 60 \\
\hline
\end{tabular}

Table 3. Annual mean speed and Weibull parameters at $50 \mathrm{~m}$ from the ground level.

\begin{tabular}{cccc}
\hline Location & Shape factor $(\mathrm{K})$ & Scale factor $(\mathrm{C})$ & $\mathrm{V}(\mathrm{m} / \mathrm{s})$ \\
\hline Al zawiya & 3.2 & 6.9 & 6.14 \\
\hline
\end{tabular}




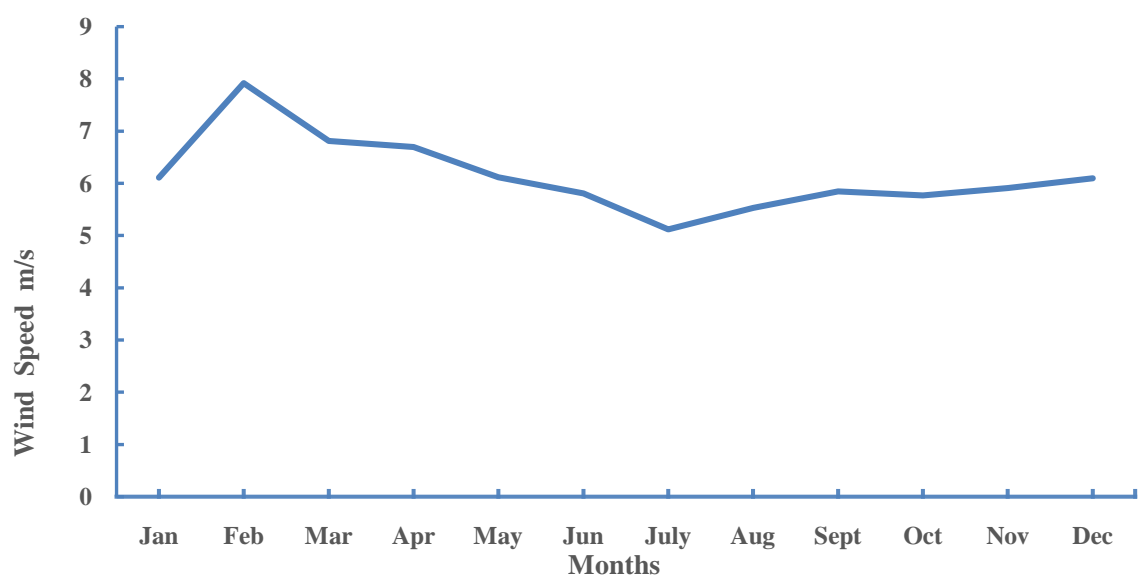

Figure 2. Monthly mean wind speed.

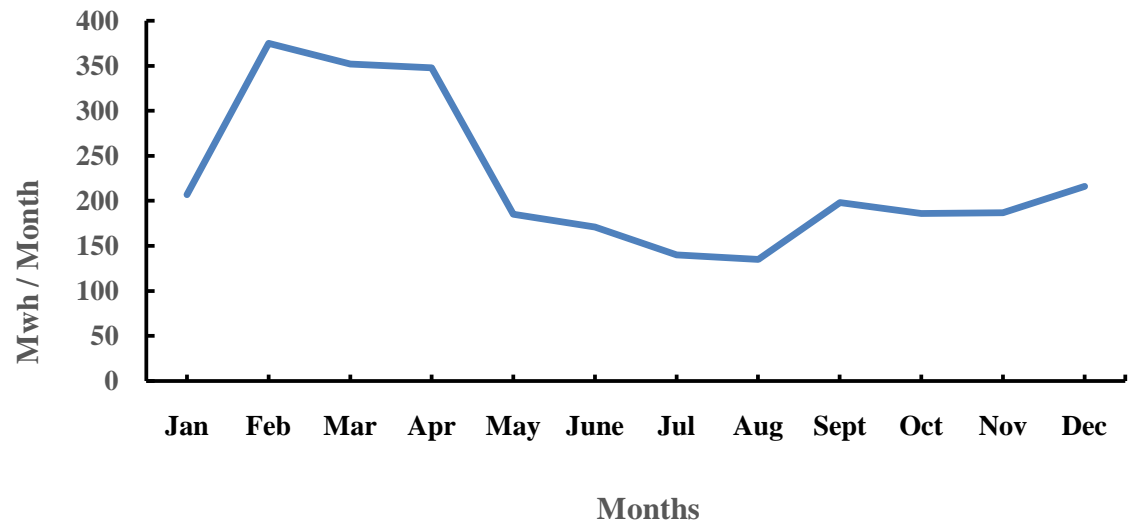

Figure 3. Monthly wind energy produced.

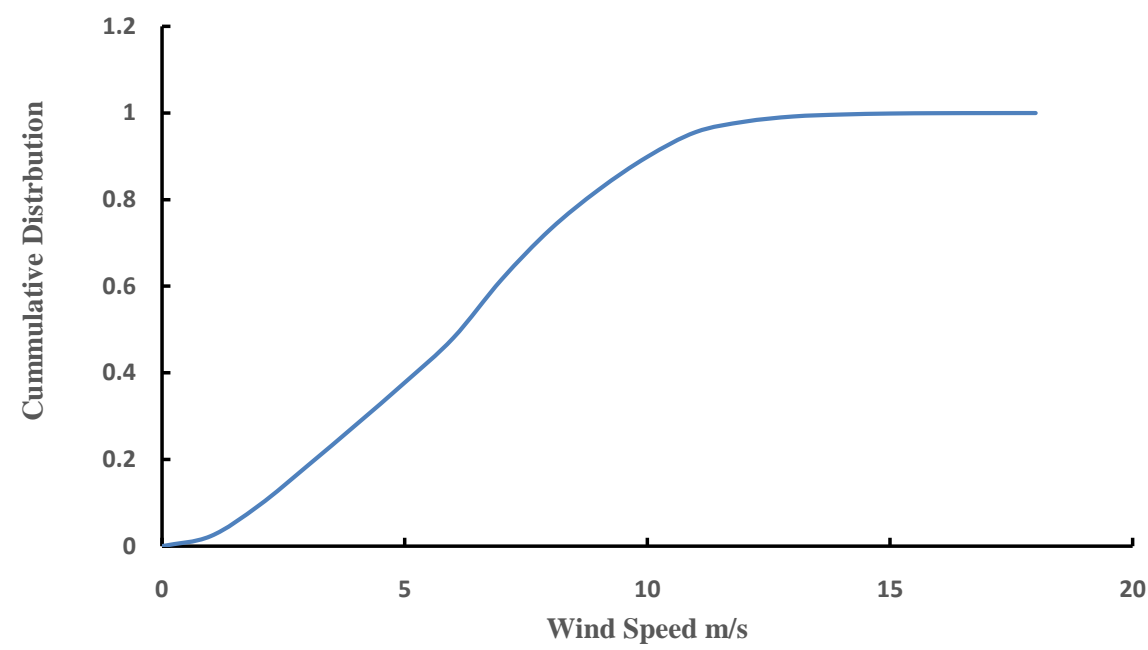

Figure 4. Annual cumulative distribution.

The seasonal Weibull wind distribution at $50 \mathrm{~m}$ is shown in Figure 6. The seasonal variation of mean wind speed and mean power density at $50 \mathrm{~m}$ are listed in Table 4. For the Zawiya region, the minimum mean wind speed is in summer with $5.5 \mathrm{~m} / \mathrm{s}$ while the maximum value of mean wind speed is in winter 


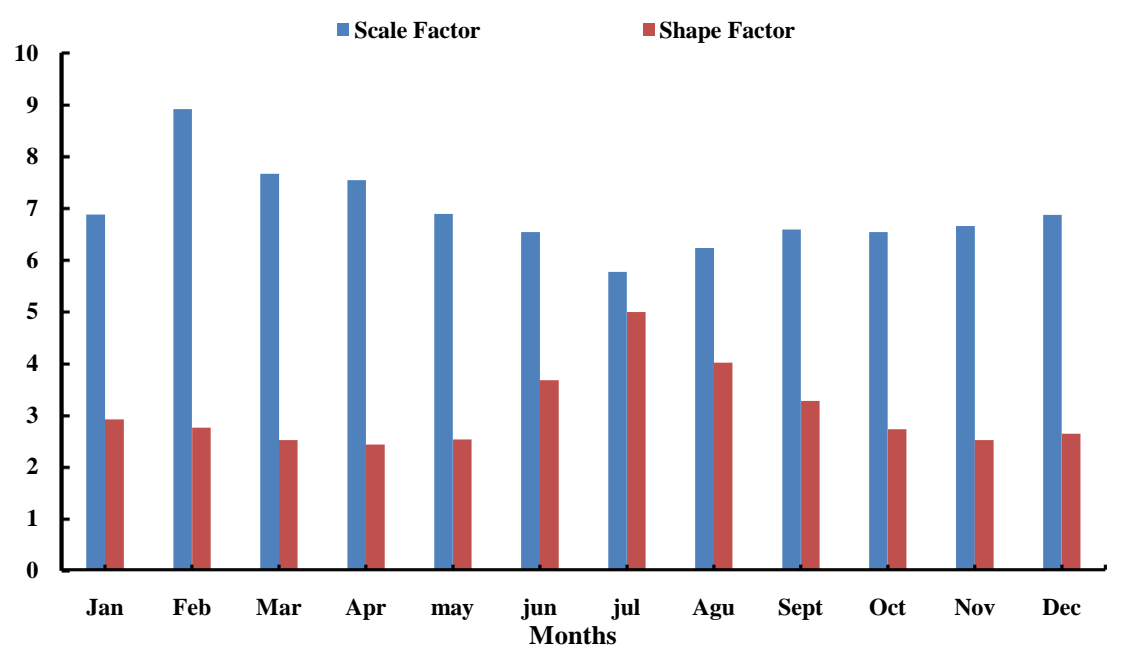

Figure 5. Monthly Weibull distribution parameters at 50 meters.

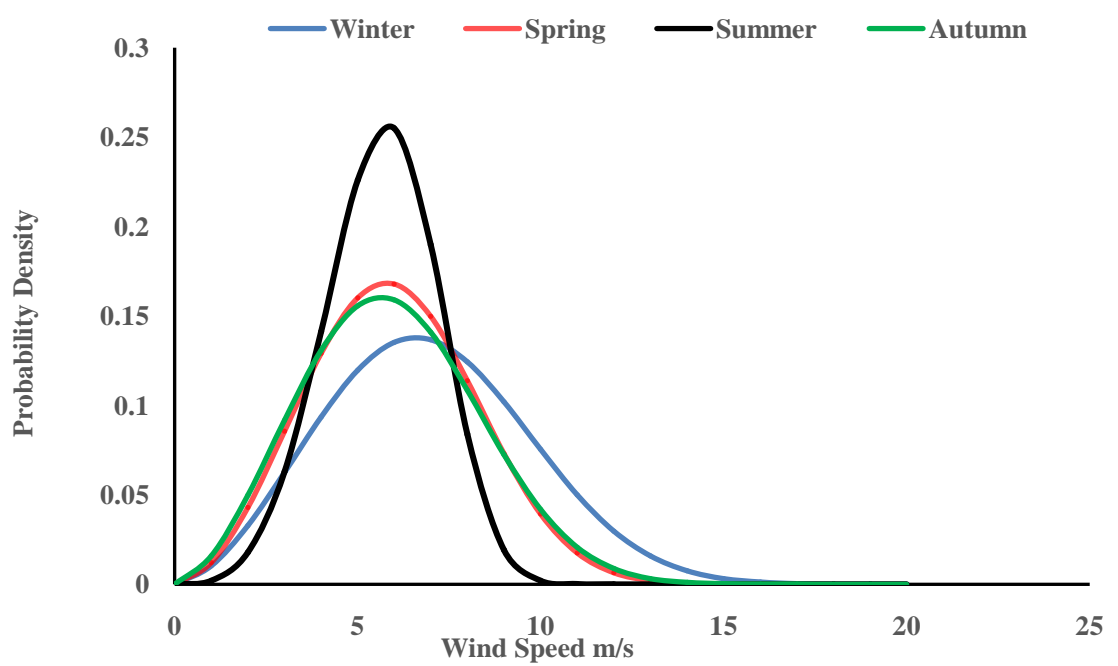

Figure 6. Seasonal Weibull wind distribution at 50 meters.

with $6.95 \mathrm{~m} / \mathrm{s}$. Moreover, the mean seasonal power density at $50 \mathrm{~m}$ varies between $183.78 \mathrm{w} / \mathrm{m}^{2}$ in summer and $401.34 \mathrm{w} / \mathrm{m}^{2}$ in winter.

From Weibull distribution, as shown in Table 5, the speed variation is maximum in winter where it reaches $[0-16 \mathrm{~m} / \mathrm{s}]$, and minimum variation is in summer where speed variation is between 0 , and $10 \mathrm{~m} / \mathrm{s}$. In the Weibull wind distribution, the greatest shape factor is 4.2 in summer season, while the worst shape factor is 2.71 in Winter. The annual Weibull distribution is illustrated in Figure 7. The production of monthly wind energy output of $750 \mathrm{kw}$ wind turbine is illustrated in Table 4 with annual energy production about $2.70 \mathrm{Gwh} /$ year.

\section{Conclusion}

The monthly, seasonal and annual Weibull parameters, mean wind speed, and wind power densities at a height of 50 meter in the Zawiya region in northwest of Libya have been determined in this study. The study shows that the site is 
Table 4. Monthly mean wind speed and power density variations at the studied site.

\begin{tabular}{cccc}
\hline Elevation & \multicolumn{3}{c}{$50 \mathrm{~m}$} \\
\hline Parameters & $\mathrm{V}[\mathrm{m} / \mathrm{s}]$ & $\mathrm{P}\left[\mathrm{w} / \mathrm{m}^{2}\right]$ & Energy Mwh/month \\
\hline January & 6.11 & 230 & 207 \\
February & 7.92 & 503.21 & 375 \\
March & 6.81 & 470.51 & 352 \\
April & 6.7 & 465.2 & 348 \\
May & 6.12 & 206.31 & 185 \\
June & 5.81 & 190.91 & 171 \\
July & 5.12 & 155.81 & 140 \\
August & 5.53 & 180.42 & 135 \\
September & 5.85 & 220.31 & 198 \\
October & 5.77 & 207.31 & 186 \\
November & 5.91 & 209.11 & 187 \\
December & 6.10 & 240.52 & 216 \\
\hline
\end{tabular}

Table 5. The seasonal mean speed and power density.

\begin{tabular}{ccc}
\hline Zawiya & \multicolumn{2}{c}{$50 \mathrm{~m}$} \\
\hline Parameter & Wind Speed $(\mathrm{m} / \mathrm{s})$ & Power Density $\mathrm{P}\left(\mathrm{w} / \mathrm{m}^{2}\right)$ \\
\hline Winter & 6.95 & 401.34 \\
Spring & 6.11 & 287.50 \\
Summer & 5.5 & 183.78 \\
Autumn & 5.92 & 218.98 \\
\hline
\end{tabular}

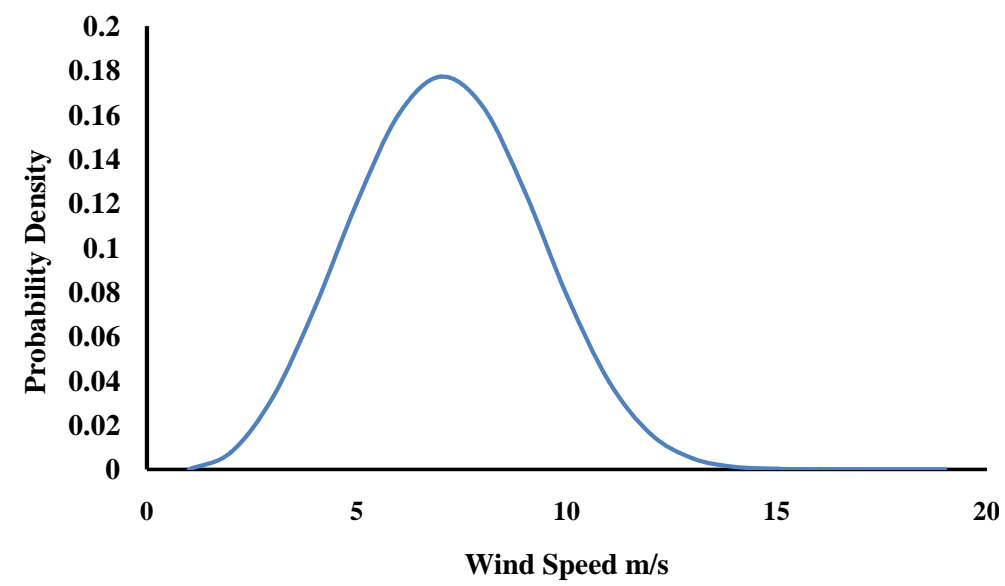

Figure 7. Annual Weibull Wind Distribution at 50 meters.

windy, and can be used to generate electricity where annual mean speed $V=$ $6.14 \mathrm{~m} / \mathrm{s}$ and 7934 hours' wind speed are between $3-19 \mathrm{~m} / \mathrm{s}$. The better performance of wind is in the winter season, as the site is in a costal side of Libya and facing to the Mediterranean Sea. The annual expectation of energy production by this site makes it virgin and promising land. The General Electric Network 
Office of Libya should integrate renewable resources through Libya's grid, where a $750 \mathrm{kw}$ wind turbine produces about $2.70 \mathrm{Gwh} /$ year.

\section{References}

[1] Masters, G.M. Renewable and Efficient Electric Power Systems. 2nd Edition.

[2] Vaughn, N. (2009) Renewable Energy and the Environment. CRC Press, Boca Raton.

[3] Department of Renewable Energy Research of Libya 2017.

[4] Sathyajith, M. (2006) Wind Energy Fundamentals, Resource Analysis and Economics. Springer Verlag, Berlin, Heidelberg, Netherlands.

[5] http://www.gecol.ly/aspx/Statistics.aspx

[6] Patel, M.R. (2006) Wind and Solar Power System. 2nd Edition, CRC Press, Boca Raton.

[7] Johnson, G.L. (2000) Wind Energy Systems. Electronic Edition, Manhattan, October.

[8] Rehman, S. and Al-Abbadi, N.M. (2008) Wind Shear Coefficient, Turbulence Intensity and Wind Power Potential Assessment for Dhulom, Saudi Arabia. Renewable Energy, 33, 2653-2660.

[9] Pallabazzer, R. (1995) Evaluation of Wind Generator Potentiality. Solar Energy, 55, 49-59.

[10] Pallabazzer, R. (1976) Parametric Analysis of Wind Siting Efficiency Statistics. Geophysical Research Letters, 3.

\section{Scientific Research Publishing}

Submit or recommend next manuscript to SCIRP and we will provide best service for you:

Accepting pre-submission inquiries through Email, Facebook, LinkedIn, Twitter, etc. A wide selection of journals (inclusive of 9 subjects, more than 200 journals)

Providing 24-hour high-quality service

User-friendly online submission system

Fair and swift peer-review system

Efficient typesetting and proofreading procedure

Display of the result of downloads and visits, as well as the number of cited articles

Maximum dissemination of your research work

Submit your manuscript at: http://papersubmission.scirp.org/

Or contact epe@scirp.org 